\title{
Exploring New Opportunities for Meaningful Research
}

\section{Carla Pavone (University of Minnesota)}

KEYWORDS: Entrepreneurship, Research Methods.

After years of being focused on theory, entrepreneurship research is broadening its scope to helping entrepreneurs solve day-to-day problems. In this video, Dr. Carla Pavone reflects on the evolving relationship between research and practice, on the institutions that are in the vanguard of this trend, and the need for research to be better designed to be meaningful to practitioners. Dr. Pavone is Associate Director of the Holmes Center for Entrepreneurship at the University of Minnesota. In that capacity, she directs the MIN-Corps program (https://eiexchange.com/content/321-Stem-studentsand-faculty-can-gain-entrepreneuri?search=STEM) , a technology commercialization program that provides entrepreneurship education and coaching to faculty, students, and researchers in STEM-related fields. She holds a Ph.D. from the University of Minnesota and an MBA from Harvard Business School. This video was prepared during the Strategic Management Society's Extension Workshop on Business Research \& Practice held in October 2019 at the U. of St. Thomas, Schulze School of Entrepreneurship. 